\title{
Feed intake, nutrient utilisation and growth performance of West African dwarf rams fed silage combinations of maize forage and Mucuna pruriens foliage
}

${ }^{1}$ Alabi, B. O. and ${ }^{2}$ Ososanya, T. O.

${ }^{I}$ Department of Animal Science, Osun State University, Ejigbo Campus, Osun State, Nigeria.

${ }^{2}$ Department of Animal Science, University of Ibadan, Ibadan, Oyo State, Nigeria.

Correspondent author: banwoaare45@gmail.com

\section{Abstract}

Crude protein is essentially needed for ruminants but expensive to supply. Mucuna puriens is a high yielding domesticated legume. When the legume is strategically combined with a fibre source, it will make a good diet for ruminants. Thus, a study was carried out to assess the effect of ensiling mucuna with maize forage on performance of rams. In the study, rams were fed silage combinations of Maize Forage (MF) and Mucuna pruriens foliage (MPF). Downy mildew and streak resistant (DMR-SR) yellow variety maize was planted and harvested as MF at six weeks of growth and ensiled with MPF at four levels: 1:0, 3:1, 1:1 and 1:3 for 21 days. All the four silages were fed to $20 \mathrm{WAD}$ rams $(12.00 \pm 0.25 \mathrm{Kg})$ in a completely randomised design for 105 days. Proximate composition of the silages, apparent nutrient digestibility of silages in WAD rams, feed intake and weight changes were determined using standard procedures, while feed conversion ratio was computed using standard procedures. Data obtained were analysed using descriptive statistics and ANOVA at $\alpha_{0.05 . . .}$ The dry matter

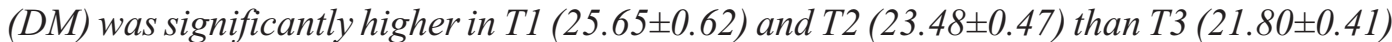

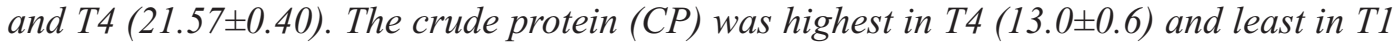

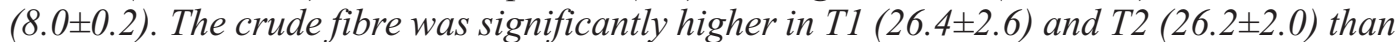

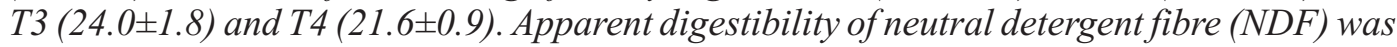
highest in $T 2(59.2 \pm 1.7)$ and least in $T 4(37.7 \pm 1.9)$, while percentage nitrogen retention was

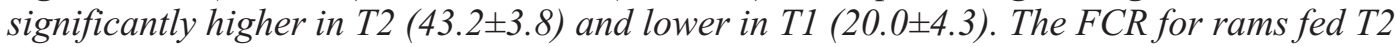

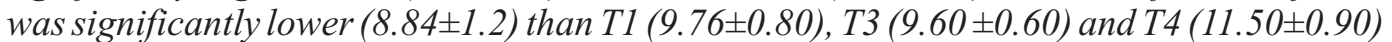

Ensiling maize forage with Mucuna pruriens foliage at 3:1 enhanced nutrient digestibility and growth performance in West African dwarf rams without any deleterious effect.

Keywords: Mucuna pruriens foliage, Maize-Mucuna silage, Ram performance, Silage digestibility

\section{Introduction}

One of the problems facing livestock production in the tropics is poor nutrition and productivity arising from inadequate feed supplies. Forages produced in this part of the world are of low quality. They grow and become lignified fast during the raining season (Williams et al., 1995) and become scarce during the dry season (Bamikole and Babayemi, 2004). This results in staggered growth pattern as animals gain weight slowly in the rainy season and lose it rapidly in the dry season (Babayemi and Bamikole, 2006).

Forages, crop residues and by-products are usually consumed fresh by domestic animals during the rainy season but become dried and lignified or scarce in the dry season. Hence the need for conservation in form of silage which is less weather dependent unlike hay, during the rainy season, when they are in abundant supply and of high nutritive value (t'Mannatje, 1999).

Ensiling is an efficient method of forage 
preservation and serves as a means of salvaging the underutilised pasture for better acceptability and degradability. Mucuna pruriens (Velvet beans) is a tropical legume belonging to the family Fabaceae of the sub-division Palpilionoideae. The plant is a vigorously growing, climbing shrub with long vines that can reach over $15 \mathrm{~m}$ in length. Mucuna pruriens has been widely promoted as a superior green manure crop in Honduras, Guinea and elsewhere (Diallo et al., 2000). Many experiments had been carried out on Mucuna pruriens seed as feed for monogastric animals (Olaboro et al., 1995, Onwneka, 1997; Iyayi and Egherevba, 1998; Iyayi et al., 2006). However, results of these experiments revealed that Mucuna pruriens have anti nutritional factors that inhibit the growth of the animals.

Maize, Guinea corn, etc. constitute the bulk of the components of livestock rations as sources of dietary energy. They constitute part of staple food for man; they are among the major arable crops produced in Nigeria especially in the savanna region (Makkar, 1994). Unlike monogastrics, feeding maize grains to ruminants as a source of dietary energy might be unrealistic because of its cost implications. However, huge tonnages of maize forage are lost during their milking stage especially due to poor soil condition and draught. Hence, there is need to convert them to the form that can be utilised by livestock such as maize forage. However, there is paucity of information on the use of maize forage as ruminant feed in Nigeria. Therefore, the present study assessed the weight changes and nutrient digestibility in WAD rams fed ensiled maize forage and Mucuna pruriens foliage.

\section{Materials and methods Studylocation}

The study was carried out at the Teaching and Research Farm of University of Ibadan, Ibadan, Nigeria.

\section{Planting of Mucuna and maize}

Two acres of land were used for the planting of mucuna and maize seeds. The land was adequately ploughed twice, harrowed once and fenced before planting to prevent accidental grazing. The plot was divided into 1 acre each for separate planting of maize and mucuna seeds. Seeds of both downy mildew/streak resistance (DMR-SR) yellow variety maize and mucuna were purchased from IITA, Ibadan. Mucuna pruriens seeds were planted at 2 seeds per hole two weeks before the planting of DMR-SR yellow variety maize at 2-3 seeds per hole. Weeding was done manually once respectively, for the Mucuna pruriens and maize at four weeks after planting during this period. Thinning was done on maize plot to 2 stands at 3 weeks after planting, while re- supplying of seeds was done on Mucuna pruriens plot at two weeks after planting.

\section{Harvesting and silage making}

Mucuna pruriens foliage was harvested at eight weeks after planting (onset of flowering) while maize was harvested at dough stage as maize forage (including maize stalks, leaves, immature cobs and tassels excluding the roots) at six weeks after planting. Harvested Mucuna pruriens foliage and maize forage were chopped into 2-3 cm pieces (for easy compaction) as recommended by t'Mannetje (1999). Chopping of forages was done by using chopping machine fabricated for the purpose of silage production located at the dairy unit of Teaching and Research Farm, University of Ibadan, Nigeria (Olorunnisomo, 2011). Thereafter, the chopped materials were wilted under shade for 24 hours on polyethene sheets spread on concrete floor. That was followed by ensiling the maize forage and Mucuna pruriens foliage in different proportions to form five dietary 


\section{Alabi and Ososanya}

treatments as follow;

- $\quad \mathrm{T} 1=1 \mathrm{MF}: 0 \mathrm{MPF}$

- $\mathrm{T} 2=3 \mathrm{MF}: 1 \mathrm{MPF}$

- $\mathrm{T} 3=1 \mathrm{MF}: 1 \mathrm{MPF}$

- $\mathrm{T} 4=1 \mathrm{MF}: 3 \mathrm{MPF}$

Dry matter determination and chemical analysis of the silage

In triplicates, $100 \mathrm{~g}$ of each silage sample was wrapped in foil paper and oven dried at $65^{\circ} \mathrm{C}$ until a constant weight was obtained for dry matter determination. Oven dried samples were then milled in the laboratory with hammer mill of $1 \mathrm{~mm}$ sieve and subjected to chemical analysis for determination of dry matter, crude protein, ash, ether extract and nitrogen free extract as described by AOAC, (1995). Neutral detergent fibre ((NDF), acid detergent fibre (ADF) and acid detergent lignin (ADL) were assayed by the methods of Van Soest et al. (1991). Hemicellulose was calculated as the difference between NDF and ADF and cellulose as the difference between ADL and ADF (Rinne et al., 1997)

\section{Digestibility study}

Twelve post weaned West African dwarf rams $(12 \pm 0.25 \mathrm{~kg})$ aged $6-8$ months were used for the experiment. They were purchased from Ikire, Osun State and Akinyele village in Oyo State. On arrival, the rams were given prophylactic intramuscular treatment of oxytetracycline and vitamin B complex at the dosage of $1 \mathrm{ml} / 10 \mathrm{~kg}$ body weight of the animal. They were also drenched with albendazole to control endo parasites and treated for mange and other ecto parasites using Ivomec.

The rams were allowed two weeks (2wks) of acclimitisation to their new environrment and the effect of the administered drugs to wear out. The design of the experiment was a completely randomized design (CRD). The rams were randomly allotted to the four dietary treatments at three rams per treatment and each ram was a replicate. Each ram was individually housed in metabolic cage with fitted facilities for separate collection of faeces and urine (Akinsoyinu, 1974). The study lasted for 14 days including 7 days of adjusted period. During the first 7 days of the experiment, the rams were introduced to the experimental silage diets and clean water were supplied ad libitum. During the last 7 days of the experiment, silage was given to each of the rams and $5 \%$ body weight, the remnants were measured and recorded in the morning of the following day to determine the daily feed intake for each ram. Also the faecal sample and urine output for each ram was measured and recorded for each of the last seven days. The urine output for each of the rams was measured using measuring cylinder and later transferred into plastic bottle and two drops of concentrated $\mathrm{HCl}$ was added to trap the air inside the plastic bottles. Also at the end of the experiment, all the faecal samples and reminants of fresh silage for each ram were bulked together, respectively. About $100 \mathrm{~g}$ each of the faecal sample and remnants of silage for each ram from the bulked samples was taken and put inside the foil paper and then oven dried at $105^{\circ}$ Cuntil a constant weight was obtained for dry matter determination. The oven dried faecal samples and remnants were later milled and stored in air tight container for proximate analysis using standard procedure of AOAC, (1995).

\section{Intake and growth performance study}

The animals' pens were made of low walls of $1.90 \mathrm{~m}$ (height) by $7.10 \mathrm{~m}$ by $13.94 \mathrm{~m}$ in size. Each pen was about $1.83 \mathrm{~m}$ long and $1.54 \mathrm{~m}$ wide. The floor of the pen was made of concrete and the roof of the sheep unit which housed the pens was made of corruagated iron sheets. The pens were washed thoroughly with detergent and were further disinfected with broad spectrum insecticide, 
acaricide and larvicide (Diazintol). The feeding and drinking troughs were washed and disinfected and the whole house was left to rest for two weeks before usage. Wood shavings were spread on the floor of the pens up to a depth of $5 \mathrm{~cm}$ as bedding materials and also to enhance prompt removal of urine and faeces and were replaced fortnightly.

Twenty post weaned West African dwarf rams with average initial body weight of $12 \pm 0.25 \mathrm{Kg}$ and $6-8$ months old were used for the experiment. They were purchased from Ikire in Osun State, Nigeria. On arrival, animals were given a prophylactic treatment which consisted of oxytetracyline long acting antibiotic (1 $\mathrm{ml} / 10 \mathrm{~kg}$ body weight of the animal) and vitamin B complex. They were also drenched with albendazole to control endoparasites and treated for mange and other ectoparasites using ivomec. During the acclimatisation period for four weeks, rams were offered local diets from where they were purchased for the first two weeks and were introduced to the experimental diets for the remaining part of the acclimatisation period. At the end of the feeding trial, animals were weighed and allotted to four dietary treatments on weight equalization basis such that the average initial weight per treatment was not statistically different. Silages were offered at $0800 \mathrm{hr}$ and $1500 \mathrm{hr}$ at $5 \%$ body weight. Ration offered was frequently adjusted to ensure that ram received $10 \%$ of feed above its previous week's consumption. For the determination of daily feed intake, the orts were deducted from total amounts served the previous day. Samples from orts were taken for proximate composition. Fresh water and feed were served ad libitum each for the 105 days duration of the experiment. Salt licks were placed permanently in each pen.
Weights of rams were taken on a weekly basis using weighing scale before the 
Alabi and Ososanya

Table 1: Proximate Composition of silage combinations of maize forage and Mucuna pruriens foliage

\begin{tabular}{|c|c|c|c|c|}
\hline \multirow[b]{2}{*}{ Parameters } & \multicolumn{3}{|c|}{ Treatments } & \multirow[b]{2}{*}{ T4 } \\
\hline & T1 & $\mathbf{T} 2$ & T3 & \\
\hline Dry Matter (\%) & $25.6^{\mathrm{a}} \pm 0.6$ & $23.4^{\mathrm{a}} \pm 0.4$ & $21.8^{\mathrm{b}} \pm 0.4$ & $21.5^{\mathrm{b}} \pm 0.4$ \\
\hline Crude Protein (\%) & $8.0^{\mathrm{c}} \pm 0.2$ & $8.9^{c} \pm 0.2$ & $11.7^{\mathrm{b}} \pm 1.3$ & $13.0^{\mathrm{a}} \pm 0.6$ \\
\hline Crude Fibre (\%) & $26.4^{\mathrm{a}} \pm 2.6$ & $26.2^{\mathrm{a}} \pm 2.0$ & $24.0^{\mathrm{ab}} \pm 1.8$ & $21.6^{\mathrm{b}} \pm 0.9$ \\
\hline Ether Extract (\%) & $2.3^{\mathrm{c}} \pm 1.2$ & $3.6^{\mathrm{b}} \pm 0.8$ & $4.6^{\mathrm{b}} \pm 1.3$ & $6.6^{\mathrm{a}} \pm 1.6$ \\
\hline $\operatorname{Ash}(\%)$ & $6.5^{\mathrm{c}} \pm 0.7$ & $8.3^{\mathrm{b}} \pm 2.3$ & $10.3^{\mathrm{b}} \pm 2.2$ & $14.3^{\mathrm{a}} \pm 1.8$ \\
\hline Nitrogen Free Extract(\%) & $56.7^{\mathrm{a}} \pm 4.3$ & $52.7^{\mathrm{b}} \pm 0.9$ & $49.1^{\mathrm{b}} \pm 1.7$ & $44.3^{\mathrm{c}} \pm 2.3$ \\
\hline
\end{tabular}

Results in Table 2 shows apparent digestibility (\%) of dry matter (ADDM), crude protein (ADCP), crude fibre (ADCF), ether extract (ADEE) and Nitrogen free extract (ADNFE). There were significant $(\mathrm{P}<0.05)$ differences in apparent digestibility of crude protein (ADCP) and crude fibre (ADCF) among the treatment means of WAD rams fed silage combinations of maize forage and Mucuna pruriens foliage. The values of ADDM ranged between $62.5 \pm 1.8 \%$ in $\mathrm{T} 1$ (1 MF: $0 \mathrm{MPF}$ ) and $66.2 \pm 0.7 \%$ in T2 (3 MF: $1 \mathrm{MPF})$. The ADCP ranged from $64.3 \pm 2.6 \%$ in $\mathrm{T} 1$ (1 MF: $0 \mathrm{MPF})$ to $76.4 \pm 2.7 \%$ in $\mathrm{T} 3$ (1 MF: $1 \mathrm{MPF})$. ADCF were $45.6 \pm 2.6 \%$ in T1(1 MF: $0 \mathrm{MPF})$, $48.1 \pm 2.6 \%$ in T2 (3 MF: $1 \mathrm{MPF}), 48.6 \pm 2.1$ $\%$ in T3 (1 MF: $1 \mathrm{MPF})$ and $47.6 \pm 1.4 \%$ in T4 (1 MF: 3 MPF), while ADEE were $66.7 \pm 4.3 \%, 66.6 \pm 3.3 \%, 65.4 \pm 4.6 \%$ and $65.0 \pm 3.8 \%$ in T1 (1 MF: $0 \mathrm{MPF}), \mathrm{T} 2$ (3 MF:1 MPF), T3 (1 MF:1 MPF) and T4 (1 MF: $3 \mathrm{MPF})$, respectively. ADNFE ranged from $53.2 \pm 3.0 \%$ in T4 (1 MF: $3 \mathrm{MPF}$ ) to $57.6 \pm 3.8 \%$ in $\mathrm{T} 1$ (1MF: $0 \mathrm{MPF}$ ). There were significant $(\mathrm{P}<0.05)$ differences in the apparently digestibility of all fibre fractions across the treatments as shown in Table 2. Apparent digestibility of Neutral detergent fibre (ADNDF) was significantly higher $59.2 \pm 1.7 \%$ in rams on T2 (3 MF: $1 \mathrm{MPF}$ ) and lowest $37.7 \pm 2.2 \%$ in rams on T4 (1 MF: 3 MPF). Apparent digestibility of acid detergent fibre (ADADF) ranged from $35.9 \pm 0.6 \%$ in rams on T4 ( $1 \mathrm{MF}: 3 \mathrm{MPF}$ ) to $56.0 \pm 1.1 \%$ in T2 (3 MF: $1 \mathrm{MPF}$ ), while the values for apparent digestibility of acid detergent lignin (ADADL) ranged from $32.0 \pm 0.8 \%$ in rams on $\mathrm{T} 4$ (1MF: $3 \mathrm{MPF})$ to $35.6 \pm 0.7 \%$ in rams on T2 ( $3 \mathrm{MF}: 1 \mathrm{MPF}$ ).

Results obtained on the nitrogen utilisation in WAD rams fed the silage combinations of maize forage and Mucuna pruriens foliage is shown in Table 3. Significant differences $(p>0.05)$ were observed in all the silage treatments in nitrogen utilisation. Voluntary feed intake (VFI), Nitrogen-intake, faecalnitrogen, urinary-nitrogen, nitrogenbalance and Nitrogen-retention ranged from $690.62 \pm 13.33$ (T1) to $798.54 \pm 15.01$ (T3)g/day,7.24 \pm 1.24 (T1) to $12.18 \pm 1.89$ (T4)g/day, $1.67 \pm 0.92$ and $1.67 \pm 1.01$ (T1 and $\mathrm{T} 2)$ to $2.79 \pm 0.89(\mathrm{~T} 4) \mathrm{g} / \mathrm{day}, 4.02 \pm 1.22$ (T1) to $6.09 \pm 0.79$ (T4)g/day, $1.55 \pm 0.72$ (T1) to $4.34 \pm 1.84$ (T2)/day, and 20.2 \pm 4.3 (T1) to $43.23 \pm 3.2 \%$ (T4), respectively. The $\mathrm{N}$ intake had the higher value of $12.18 \pm 1.89 \mathrm{~g} /$ day in rams on T4 (1 MF: 3 $\mathrm{MPF}$ ) and lowest $7.24 \pm 1.24 \mathrm{~g} /$ day in rams on 
West African dwarf rams fed silage combinations of maize forage and Mucuna pruriens foliage

Table 2: Apparent digestibility Coefficients (\%) in West African dwarf rams fed silage combinations of maize forage and Mucuna pruriens foliages

\begin{tabular}{lllll}
\hline \multirow{2}{*}{ Parameters } & \multicolumn{4}{c}{ Treatments } \\
\cline { 2 - 5 } & T1 & T2 & T3 & T4 \\
\hline Dry Matter & $62.5^{ \pm} \pm 1.8$ & $66.2 \pm 0.7$ & $66.0 \pm 1.3$ & $63.6 \pm 1.5$ \\
Crude Protein & $64.3^{\mathrm{c}} \pm 2.6$ & $76.0^{\mathrm{a}} \pm 2.3$ & $76.4^{\mathrm{a}} \pm 2.7$ & $69.6^{\mathrm{b}} \pm 2.2$ \\
Crude Fibre & $45.6^{\mathrm{c}} \pm 2.6$ & $48.1^{\mathrm{a}} \pm 2.6$ & $48.6^{\mathrm{a}} \pm 2.1$ & $47.6^{\mathrm{b}} \pm 1.4$ \\
Ether Extract & $66.7 \pm 4.3$ & $66.6^{ \pm} 3.3$ & $65.4^{ \pm} 4.6$ & $65.0 \pm 3.8$ \\
Nitrogen Free Extract & $57.6^{ \pm} \pm 3.8$ & $56.8 \pm 2.7$ & $56.2 \pm 3.4$ & $53.2 \pm 3.0$ \\
Neutra ldetergent fibre & $54.6^{\mathrm{b}} \pm 2.8$ & $59.2^{\mathrm{a}} \pm 1.7$ & $41.1^{\mathrm{c}} \pm 1.9$ & $37.7^{\mathrm{d}} \pm 2.2$ \\
Acid detergent fibre & $51.2^{\mathrm{b}} \pm 0.4$ & $56.0^{\mathrm{a}} \pm 1.1$ & $42.6^{\mathrm{c}} \pm 0.6$ & $35.9^{\mathrm{d}} \pm 0.6$ \\
Acid detergent ligin & $34.2^{\mathrm{a}} \pm 0.6$ & $35.6^{\mathrm{a}} \pm 0.7$ & $32.3^{\mathrm{b}} \pm 1.0$ & $32.0^{\mathrm{b}} \pm 0.8$ \\
\hline
\end{tabular}

a,b,e: Means in the same row with different superscript are significantly different $(P<0.05)$.

T1 = 1 MF: 0 MPF; T2 = 3 MF: 1 MPF; T3=1MF: 1 MPF; T4 = 1 MF: 3 MPF; MF - Maize Forage; MPF -Mucuna pruriens Foliage

T1 (1 MF: 0 MPF). The N-balance was significantly higher $4.34 \pm 1.84 \mathrm{~g} /$ day in WAD rams on T2 (3 MF: $1 \mathrm{MPF}$ ) and lowest $1.55 \pm 0.72 \mathrm{~g} /$ day in WAD rams on $\mathrm{T} 1$ (1 MF: $0 \mathrm{MPF}$ ), also the same trend was observed for the $\mathrm{N}$ - retention (\%)

Results in Table 4 showed the intake and weight changes in WAD rams fed the silage combinations of maize forage and Mucuna pruriens foliage. Significant differences $(p<0.05)$ were observed for Final body weight (FBW), body weight gain (BWG), daily body weight gain (DBWG), dry matter intake (DMI) and feed conversion ratio (FCR) among the treatment means. The BWG of WAD rams on T2 (3 MF: 1 MPF) was significantly higher $11.63 \pm 1.83$ Kg compared to $8.67 \pm 2.22 \mathrm{Kg}$ in T1 (1 MF: $0 \mathrm{MPF}$ ), $10.67 \pm 2.04 \mathrm{Kg}$ in T3 (1 MF: 1 $\mathrm{MPF})$ and $7.25 \pm 2.67 \mathrm{Kg}$ in $\mathrm{T} 4$ (1 MF: 3 MPF), respectively. The FCR was highest $11.50 \pm 0.90$ for rams on T4 (1 MF: 3MPF), while it was lowest $8.48 \pm 1.20$ for rams on T2 (3 MF: $1 \mathrm{MPF}$ ).

\section{Discussion}

The dry matter (DM) values obtained in the present study were similar to the range of values of $20-27 \%$ reported by Moran (2005) for tropical forages but lower than 30 - 35\% reported by FAO (2000). The differences could be as a result of certain factors such as age of harvesting the forage materials, additives used, ensiling technique, and silo materials.

The crude protein (CP) and ether extract (EE) increased with increasing inclusion of Mucuna pruriens foliage in the silage, while the DM, Crude fibre (CF) and nitrogen free extract (NFE) decreased with increasing level of Mucuna pruriens foliage in the silage. The CP in T1 (1 MF: $0 \mathrm{MPF}$ ) and T2 (3 MF: $1 \mathrm{MPF}$ ) were within the critical value of $7 \%$ recommended for small ruminants (ARC, 1980). The silage of T3 (1 MF: $1 \mathrm{MPF})$ was within the minimum protein requirement of $10-12 \%$ recommended by ARC (1984) for ruminants, while the CP contents of T4 (1 MF: 3 MPF) was slightly above the minimum recommended value by ARC (1984). The ash content represents the inorganic mineral matter in a feed. Its value is mainly the contents of phosphorous, calcium and potassium and amounts of silica 


\section{Alabi and Ososanya}

Table 3: Nitrogen utilisation by WAD rams fed silage combinations of maize forage and

Mucuna pruriens foliage

\begin{tabular}{|c|c|c|c|c|}
\hline \multirow[b]{2}{*}{ Parameters } & \multicolumn{3}{|c|}{ Treatments } & \multirow[b]{2}{*}{ T4 } \\
\hline & $\mathbf{T} 1$ & $\mathbf{T 2}$ & T3 & \\
\hline VFI (g/day) & $690.62^{c} \pm 13 . .22$ & $784.07^{\mathrm{a}} \pm 14.04$ & $798.54^{\mathrm{a}} \pm 15.01$ & $693.28^{c} \pm 11.11$ \\
\hline N- Intake (g/day) & $7.24^{\mathrm{b}} \pm 1.24$ & $10.04^{\mathrm{a}} \pm 1.02$ & $10.82^{\mathrm{a}} \pm 1.66$ & $12.18^{\mathrm{a}} \pm 1.89$ \\
\hline $\mathrm{N}$ - Urine (g/day) & $4.02^{\mathrm{c}} \pm 0.92$ & $4.03^{\mathrm{c}} \pm 1.01$ & $5.38^{\mathrm{b}} \pm 0.98$ & $6.09^{\mathrm{a}} \pm 0.89$ \\
\hline $\mathrm{N}$ - faeces (g/day) & $1.67^{\mathrm{b}} \pm 1.22$ & $1.67^{\mathrm{b}} \pm 1.46$ & $2.08^{\mathrm{a}} \pm 0.88$ & $2.79^{\mathrm{a}} \pm 0.79$ \\
\hline N-total excreted (g/day) & $5.69^{b} \pm 1.02$ & $5.70^{\mathrm{b}} \pm 0.64$ & $7.46^{\mathrm{a}} \pm 2.13$ & $8.88^{\mathrm{a}} \pm 1.47$ \\
\hline $\mathrm{N}$ - balance (g/day) & $1.55^{\mathrm{c}} \pm 0.72$ & $4.34^{\mathrm{a}} \pm 1.84$ & $3.36^{\mathrm{b}} \pm 1.36$ & $3.30^{\mathrm{b}} \pm 0.88$ \\
\hline $\mathrm{N}-$ retention $(\%)$ & $20.0^{\mathrm{d}} \pm 4.3$ & $43.2^{\mathrm{a}} \pm 3.8$ & $31.0^{\mathrm{b}} \pm 2.3$ & $27.0^{c} \pm 3.2$ \\
\hline
\end{tabular}

Table 4: Feed intake and growth performance in WAD rams $f$ ed silage combinations of maize forage and Mucuna pruriens foliage

\begin{tabular}{|c|c|c|c|c|}
\hline \multirow[t]{2}{*}{ Parameters } & \multicolumn{3}{|c|}{ Treatments } & \multirow[b]{2}{*}{$\mathrm{T} 4$} \\
\hline & $\mathrm{T} 1$ & $\mathrm{~T} 2$ & $\mathrm{~T} 3$ & \\
\hline IBW (kg) & $12.00 \pm 0.25$ & $11.75 \pm 0.37$ & $12.00 \pm 0.25$ & $12.00 \pm 0.24$ \\
\hline FBW (kg) & $20.67^{b} \pm 1.65$ & $23.38^{\mathrm{a}} \pm 1.82$ & $22.67^{\mathrm{ab}} \pm 1.02$ & $19.25^{\mathrm{c}} \pm 2.02$ \\
\hline BWG (kg) & $8.67^{\mathrm{ab}} \pm 2.22$ & $11.63^{\mathrm{a}} \pm 1.83$ & $10.67^{\mathrm{b}} \pm 2.04$ & $7.25^{\mathrm{c}} \pm 2.67$ \\
\hline DBWG (g/day) & $82.57^{c} \pm 7.28$ & $110.76^{\mathrm{a}} \pm 6.44$ & $101.62^{b} \pm 10.03$ & $69.05^{\mathrm{d}} \pm 8.42$ \\
\hline DMI (g/day) & $806.38^{c} \pm 11.12$ & $869.39^{\mathrm{a}} \pm 12.08$ & $872.41^{b} \pm 19.04$ & $794.76 \pm 15.44^{\mathrm{d}}$ \\
\hline FCR & $9.76^{\mathrm{b}} \pm 0.80$ & $8.48^{\mathrm{c}} \pm 1.20$ & $9.60^{\mathrm{b}} \pm 0.60$ & $11.50^{\mathrm{a}} \pm 0.90$ \\
\hline
\end{tabular}

(Bogdan, 1977). The ether extract of the silages ranged from $2.2 \%$ in T1 (1 MF: 0 MPF) to $6.6 \%$ in T4 (1 MF: $3 \mathrm{MPF}$ ). Ether extract is the lipid fraction, which is a major form of energy storage in plant. The energy derivable from the plant is what animal uses for its body maintenance and production. The results from the present study showed that the silages had sufficient energy. The crude fibre (CF) contents of the silages $(21.6$ - 26.42) revealed that the silage would produce effective rumination in which rumen microbes can degrade to produce sources of energy for the rams. Decrease in NFE percentage across the treatments was a good indication that maize forage has high soluble carbohydrates needed for effective fermentation of forage combinations during ensiling.

Digestibility of feed is classified as high ( $>$ $60 \%)$, medium (40-60\%) and low $(<40 \%)$ (FAO, 2000). According to FAO (2000), the apparent digestibility was high for all the nutrients except medium values recorded for nitrogen free extract (NFE), neutral detergent fibre (NDF) and acid detergent fibre (ADF), respectively. However, low values were obtained for acid detergent lignin (ADL) across the dietary treatments. The apparent dry matter digestibility (ADDM) for all the silages was similar statistically. Non-significant values obtained in this present study for ADDM indicated that silage dry matter digestibility 


\section{West African dwarf rams fed silage combinations of maize forage and Mucuna pruriens foliage}

by WAD rams was similar and this was similar to the study conducted by Morris et al. (2005).

The apparent digestibility of dry matter did not follow any particular trend across the treatments in this study. However, T2 (3 MF: 1 MPF) had the highest ADDM followed by $\mathrm{T} 3$ (1 MF: $1 \mathrm{MPF}$ ) and followed by T4 (1 MF: 3MPF), while T1 (1MF: 0 MPF) had the least. These results obtained were in line with the work of Nour et al. (1987) and Elkholy et al. (2009) who reported higher values of ADDM, respectively. Similar result was also observed by Babayemi (2009) who obtained a higher digestibility value in study conducted using Guinea grass silage to feed WAD sheep. The higher values of ADDM obtained in this study revealed that, dry matter is not a limiting factor for silage intake and digestibility when ensiled maize forage and Mucuna pruriens is used in feeding ruminants, which could be of great benefits to the animals.

The apparent digestibility of crude protein (ADCP) increased with increased level of Mucuna pruriens foliage in the silage from T1 (1 MF: $0 \mathrm{MPF})$ to T3 (1 MF: 1 MPF) and later decreased in T4 (1 MF: 3MPF). High crude protein digestibility has been considered an important factor that enables high intake of the silage. However, apparent crude protein digestibility values in the present study were higher than what was reported by Taiwo et al. (1995). This may be due to the Mucuna pruriens foliage having higher crude protein content.

The Crude fibre digestibility in this study was similar to those reported by Nour et al. (1987) and Elkholy et al. (2009), respectively. The factors responsible might be level of silage intake and stages of harvest of ensiled forage materials which may affect the fibre digestion (Scholljegerdes et al., 2004). Nour et al.
(1987) also reported that decreasing fibre digestibility is correlated with decreased forage intake. However, the higher crude fibre digestibility for WAD rams in all the silages in this study might be due to proliferation of fibrolytic microorganisms or increased activities of fibre digesting fungi and fibrolytic bacteria in the rumen of the rams on the feed due to adaptation and nature of the diet. The apparent digestibility of ether extract (ADEE) obtained in the present study was higher than those obtained (44.79 $59.61 \%$ ) by Nour et al. (1987) but lower than $81.83-85.68 \%$ for maize stover treated with yeast and urea fed to lamb in the studies conducted by Sabbah et al. (2006) and Elkholy et al. (2009).

The apparent digestibility of nitrogen free extract (ADNFE) decreased with an increased level of Mucuna pruriens foliage in the silage. The values obtained in the present study were lower than the values obtained by Sabbah et al. (2006) and Elkholy et al. (2009). They reported that the NFE digestibility (\%) of cross bred Rahmany male lambs fed on rations containing corn stover silage with $5 \mathrm{~g}$ yeast/head/day was $80.34 \%$. The non-significant differences on the apparent digestibility of neutral detergent fibre (ADNDF) in the dietary treatments in this study showed that the fibre fractions were relatively digested by WAD rams which was the expectation since rams are ruminants and have the ability to digest cellulose (Elkholy et al., 2009).

The nitrogen $(\mathrm{N})$ as a precursor of protein is also one of the most limiting nutrients for ruminant animal production apart from energy. Therefore, it is very important to incorporate this nutrient in a feeding system based on low nitrogen fibrous diet. The nitrogen balance (g/day) of WAD rams on the silages was in the order of T2>T3>T4> $\mathrm{T} 1$, all with positive N-balance. The $\mathrm{N}$ retention followed a similar trend from 20.0 